\title{
Ecological stoichiometry in six species of Antarctic marine benthos
}

\author{
Andrew Clarke* \\ Biological Sciences, British Antarctic Survey, NERC, High Cross, Madingley Road, Cambridge CB3 0ET, UK
}

\begin{abstract}
Elemental (C, N, P) composition was examined in 6 benthic marine invertebrates from Antarctica: 2 suspension feeders (the holothurian Heterocucumis steineni and the polychaete Thelepus cincinnatus), 1 epifaunal grazer (the limpet Nacella concinna), 1 deposit feeder (the polychaete Flabelligera mundata), 1 predator (the nemertean Parborlasia corrugatus) and an omnivore (the asteroid Odontaster validus). Correction for inorganic carbon was necessary only for O. validus, where skeletal carbonate produces a high mineral ash content. Elemental composition of tissue was 49 to $60 \% \mathrm{C}$, 10 to $14 \% \mathrm{~N}$ and 0.7 to $1.3 \% \mathrm{P}$ (all on an organic mass basis); these are all within the normal range of values for aquatic invertebrates. The most variable component was $\mathrm{P}$, though variability was much lower than in stream insects. Stoichiometric molar ratios (C:P, C:N, N:P) were all typical of consumers, with a strong inverse relationship across species between \% $\mathrm{C}$ and \% $\mathrm{N}$ in tissue. Stoichiometry varied strongly between phyla, with less variation between species within phyla. There were also indications of variations in elemental composition ( $\mathrm{C}: \mathrm{N}$ ratio and \% $\mathrm{P}$ ) with feeding mode, but the limited range of taxa studied constrains this conclusion. Despite differences in nutrient status, the elemental composition of marine and freshwater benthos were, with the exception of insects, closely similar. Despite the very slow growth rates that characterise polar marine benthos, $\mathrm{P}$ contents were relatively high, suggesting that the predictions of the growth rate hypothesis are not upheld at low temperatures.
\end{abstract}

KEY WORDS: Stoichiometry · Benthos · Antarctic $\cdot$ Phosphorus · Growth Resale or republication not permitted without written consent of the publisher

\section{INTRODUCTION}

The elemental composition of all life on earth is dominated by $\mathrm{C}, \mathrm{H}, \mathrm{N}, \mathrm{O}, \mathrm{P}$ and $\mathrm{S}$. These are all small atoms that are common in the environment and fairly reactive through a tendency to share electrons (Fraústo da Silva \& Williams 2001). Ecological stoichiometry has been concerned primarily with $\mathrm{C}, \mathrm{N}$ and $\mathrm{P}$. Whilst there is increasing recognition of the importance of minor elements in regulating large-scale ecological processes (for example the role of iron or other micronutrients in limiting oceanic primary productivity), and also a developing interest in their stoichiometric behaviour (Karimi \& Folt 2006), the bulk of theory is built around the dynamics of $\mathrm{C}, \mathrm{N}$ and $\mathrm{P}$ in organisms and ecosystems (Sterner \& Elser 2002).
The flux of material through food webs is dictated by thermodynamics and the conservation of mass. Thus, analysis of the movement of specific elements through food webs provides insight into the functional relationships which underpin ecosystem function (Lotka 1925, Lindemann 1942, Reiners 1986). Current interest in the ecological stoichiometry of aquatic systems can be traced back to the seminal observations of Redfield et al. (1963) on $\mathrm{N}$ and $\mathrm{P}$ in the global ocean, and the recognition that phytoplankton growing in non-limiting conditions of light and nutrients typically exhibit a more or less constant ratio of $\mathrm{P}$ and $\mathrm{N}$ to $\mathrm{C}$ (106 C: $16 \mathrm{~N}: 1 \mathrm{P}$, the Redfield ratio). Although phytoplankton with markedly different elemental compositions have been reported from both marine and freshwater habitats, Redfield stoichiometry has long been taken as an 
indication of the optimal tissue composition of healthy, actively growing, non-limited microalgae (Hillebrand \& Sommer 1999). Recent work has, however, suggested that Redfield stoichiometry falls within a range of normal values for marine microalgae (Geider \& La Roche 2002) and that for aquatic seston stoichiometry is scale dependent (Sterner et al. 2008).

Ecological stoichiometry has proved particularly valuable in the study of freshwater systems where $\mathrm{N}$, and especially P, can be severely limiting (Guildford \& Hecky 2000). Studies of herbivorous zooplankton in lakes have shown that Redfield stoichiometry is not preserved at the second trophic level (herbivory), and aquatic zooplankton consumers can have widely divergent stoichiometries (Anderson et al. 2004, 2005). It is now clear that herbivorous zooplankton in lakes can exert a powerful control of phytoplankton population dynamics and assemblage composition through grazing and recycling of key nutrients (Elser \& Urabe 1999, Sterner \& Elser 2002). There have been fewer studies of benthic grazers in freshwater systems, but analysis of benthic invertebrates has shown that $\mathrm{C}, \mathrm{N}$ and $\mathrm{P}$ stoichiometry varies with taxon, species and site (EvansWhite et al. 2005, Liess \& Hillebrand 2005).

It is generally accepted that primary production in the sea is limited by $\mathrm{N}$ rather than $\mathrm{P}$ (although it may be that the availability of $\mathrm{P}$ sets an overall constraint on global primary production in the sea, Tyrrell 1999) (but see Elser et al. 2007). In most areas of the ocean primary production reduces ambient levels of $\mathrm{N}$ and $\mathrm{P}$, with $\mathrm{N}$ often reaching exhaustion despite remineralisation within the mixed layer; nutrient levels are reestablished by winter mixing and other transfer processes from deep water. Although there has been a considerable modelling effort directed at understanding the dynamics of $\mathrm{C}$ and $\mathrm{N}$ (and to an increasing extent, P) in the oceanic mixed layer, few studies have examined processes below the mixed layer, and most have been concerned with the first 2 trophic levels (primary production and herbivory) or the microbial loop. To date the third major sink for marine primary production, the benthic environment, has received little attention.

The Southern Ocean is unusual in that in many areas the summer phytoplankton bloom does not reduce either $\mathrm{N}$ or $\mathrm{P}$ to levels that would traditionally be regarded as limiting. In some areas, however, notably intense blooms in the marginal ice zone (Jennings et al. 1984, Iwanami et al. 1986) or close to shore (Clarke \& Leakey 1996, Clarke et al. 2008), N and P concentrations within the summer mixed layer can be reduced to classically limiting concentrations.

The aim of this study was to undertake a preliminary investigation of the elemental stoichiometry of selected Antarctic benthic marine invertebrates. In addition to analysis for $\mathrm{C}, \mathrm{N}$ and $\mathrm{P}$, the water, mineral ash and inorganic carbon content were also measured to allow stoichiometry to be calculated on the basis of both dry mass and tissue organic matter. The organisms used in this study were collected from shallow depths that were within the summer mixed layer, and hence were within an environment that was typically nutrient replete for the primary producers on which they ultimately depend. The overall aim of the study was to determine the extent to which stoichiometric relationships established in freshwater habitats (Sterner \& Elser 2002, Evans-White et al. 2005, Liess \& Hillebrand 2005) apply to benthic consumers in an environment that is generally nutrient replete. The key question was therefore: How does the C, N and P stoichiometry of benthic marine invertebrates compare with patterns established for consumers in other habitats? Secondary questions were: (1) Are there any stoichiometric features common to all marine benthic taxa examined? (2) Are there any patterns in the stoichiometry that relate to trophic type?

\section{MATERIALS AND METHODS}

Species selection and sampling. The 6 benthic taxa chosen for this study were selected to cover a range of taxonomic groups (Table 1).

Parborlasia corrugatus is an unusually large nemertean and an important predator in the shallow waters of Antarctica. It consumes a wide range of prey items and can reach a size of over $1 \mathrm{~m}$ (Gibson 1983). Aspects of its physiology have been discussed by Heine et al. (1991), Clarke \& Prothero-Thomas (1997) and Davison \& Franklin (2002). In this study we analysed a range of sizes, from 0.1 to $12.2 \mathrm{~g}$ dry mass; 82 individuals were from Signy and 29 from Rothera, all collected in summer.

Nacella concinna is the only common limpet found throughout the maritime Antarctic, grazing on microbial films and microphytobenthos in the intertidal and shallow subtidal zones. Its growth rate is slow (Clarke et al. 2004), and its physiology highly seasonal (Fraser et al. 2002, 2007); aspects of its nitrogen metabolism have been reported by Clarke (1990) and Clarke et al. (1994). In the present study I analysed limpets ranging from 11.0 to $49.5 \mathrm{~mm}$ in shell length, and 0.414 to $1.471 \mathrm{mg}$ in tissue dry mass; 30 were from Signy (summer) and 89 from Rothera (50 in winter, 39 in summer).

Flabelligera mundata is a moderately large depositfeeding polychaete, reasonably common in the shallow waters around Rothera. Little is known of its general biology, apart from its reproductive biology (Pearse et al. 1991). Thirty worms were sampled from Rothera in summer, ranging in dry mass from 0.068 to $3.01 \mathrm{~g}$. 
Table 1. Characteristics of taxa used in this study

\begin{tabular}{|c|c|}
\hline Species & Comments \\
\hline \multicolumn{2}{|l|}{ Nemertea } \\
\hline Parborlasia corrugatus (McIntosh, 1876) & Predatory and scavenging worm, ingesting prey items whole \\
\hline \multicolumn{2}{|l|}{ Mollusca } \\
\hline Nacella concinna (Strebel, 1908) & Limpet. Grazer of subtidal and intertidal microbial films and microphytobenthos \\
\hline \multicolumn{2}{|l|}{ Polychaeta } \\
\hline Flabelligera mundata Gravier, 1906 & Epifaunal, deposit feeding worm \\
\hline Thelepus cincinnatus (Fabricius, 1780) & Terebellid polychaete, building tubes from sediment. Epifaunal suspension feeder \\
\hline \multicolumn{2}{|l|}{ Echinodermata } \\
\hline Odontaster validus (Köhler, 1906) & Cushion-star (asteroid). Omnivore, diet includes carrion, seal faeces, and phytodetritus \\
\hline Heterocucumis steineni (Ludwig, 1898) & $\begin{array}{l}\text { Dendrochirate holothurian. Epifaunal suspension feeder, taking mainly larger cells, } \\
\text { especially diatoms }\end{array}$ \\
\hline
\end{tabular}

Thelepus cincinnatus is a widely distributed terebellid polychaete, common in shallow waters. It is possible that detailed taxonomic work, and especially the application of molecular tools, will demonstrate that this is actually a species complex, but at present this is the one organism selected for study that appears to be distributed widely outside the Southern Ocean. A typical terebellid, T. cincinnatus is a suspension feeder, building a sediment tube that allows it to feed higher into the water column. At Rothera its feeding tentacles can form a dense canopy in some areas of shallow water. Thirty worms were sampled in winter (when they are not feeding), and a further 27 were sampled during the period of active summer feeding. They ranged in size from 0.41 to $2.35 \mathrm{~g}$ dry mass.

The cushion star Odontaster validus is one of the commonest members of the shallow water benthos all around Antarctica. It is a slow-growing omnivore, the general and reproductive biology of which have been studied extensively at McMurdo Sound (Pearse 1965, 1969, McClintock et al. 1988), Signy Island (StanwellSmith \& Clarke 1998, Stanwell-Smith \& Peck 1998) and Rothera Point, Adelaide Island (Grange et al. 2007). In this study we analysed 16 individuals from Signy and 39 from Rothera (both groups collected in summer).

Heterocucumis steineni is a very common, shallow water suspension-feeding holothurian. Little is known of its general biology, although at both Signy Island and Rothera Point diatoms form an important component of its diet and it shows a markedly seasonal pattern of feeding (Fraser et al. 2004). Twelve individuals were analysed from Rothera in winter, and 6 in summer.

All 6 species are common in shallow water around Antarctica and can be sampled easily and cleanly by SCUBA divers. To minimise any effect on the sampled populations, analyses were performed, in most cases, on individuals that had been collected for other purposes. On the basis of preliminary work the minimum sample size was set at 15; only in 1 species (Heterocu- cumis steineni) was this not achieved for any site. A preliminary study of 3 species (Nacella concinna, Parborlasia corrugatus, $H$. steineni) was undertaken at Signy Island, South Orkney Islands $\left(60^{\circ} 43^{\prime} \mathrm{S}\right.$, $45^{\circ} 36^{\prime} \mathrm{W}$ ) in January 1994 , with the main study of all size species based on collections made at Rothera Point, Adelaide Island $\left(67^{\circ} 34^{\prime} \mathrm{S}, 68^{\circ} 08^{\prime} \mathrm{W}\right)$ in June and July 2000 (winter samples) and January 2001 (summer samples); these sites are shown in Fig. 1. All organisms were collected individually by SCUBA divers from depths of 15 to $20 \mathrm{~m}$, and returned immediately to the

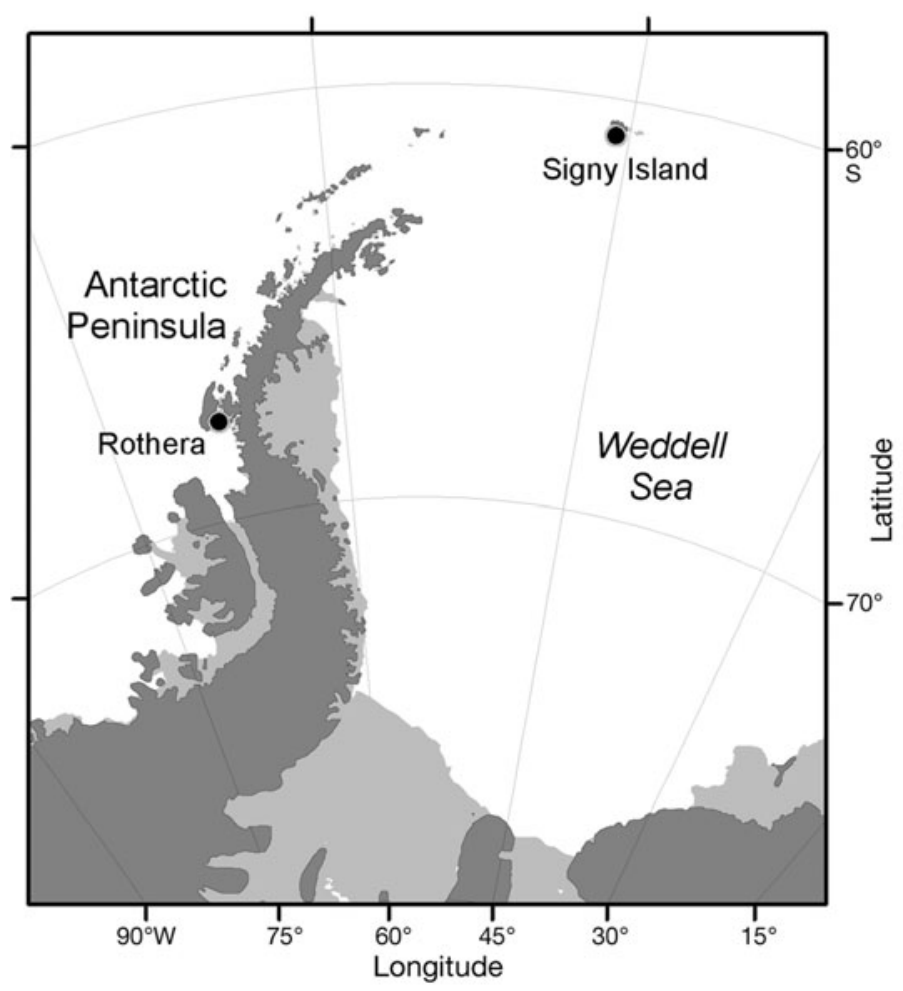

Fig. 1. The Antarctic Peninsula showing the location of the 2 sample sites for the species examined in this study. Land is shown in dark grey and ice shelves are in light grey 
laboratory, where they were maintained in running seawater at ambient temperature for a maximum of several hours before analysis.

Biomass determination. Wet mass was determined after gently rolling samples in a tissue to remove excess external water. Before wet mass determination, the terebellid worm Thelepus cincinnatus was removed carefully from its sediment tube, and the limpet Nacella concinna was shucked from its shell. All other taxa were analysed as sampled.

Dry mass was determined after drying to constant weight in an oven at $60^{\circ} \mathrm{C}_{\text {; }}$ for most individuals $24 \mathrm{~h}$ drying was sufficient, but for some larger individuals $76 \mathrm{~h}$ were needed. The samples were then ground to a fine powder and stored dry in closed vials at $-20^{\circ} \mathrm{C}$ for further analysis. Ash content was determined by igniting a subsample of $\sim 0.5 \mathrm{~g}$ at $550^{\circ} \mathrm{C}$ in a muffle furnace, using a temperature ramp of $0.5 \mathrm{~K} \mathrm{~s}^{-1}$. All samples were re-dried prior to ignition, and ash samples were retained for measurement of inorganic carbon.

Elemental analysis. Carbon and nitrogen were measured on subsamples of dried tissue and ash, using a Carlo Erba 1106 elemental analyser. Dry tissue samples were typically 1 to $2 \mathrm{mg}$, and ash samples were typically 10 to $20 \mathrm{mg}$. All samples were run in duplicate, with carrier gas blanks, sample blanks (empty tin sample vials) and acetanilide standards run every 5th set of duplicate samples. There was no significant trend in calibration with time, and so elemental composition was calculated on the basis of a mean for all blanks and acetanilide standards run for each species. Median within-replicate coefficients of variation (CV) were $2.8 \%$ for $\mathrm{C}$ and $3.2 \%$ for $\mathrm{N}$.

Phosphorus was measured by reaction with ammonium molybdate following digestion with $72 \%$ perchloric acid (Fiske \& Subbarow 1925). Samples (typically 3 to $5 \mathrm{mg}$ ) were digested at $180^{\circ} \mathrm{C}$, using long pyrex tubes in a heater block and allowing the digest to reflux within the tube. Digestion was for $30 \mathrm{~min}$ or longer if this was needed for the digest to clear completely. Each individual assay run was calibrated with a standard curve (6 duplicate concentrations) erected with $\mathrm{KH}_{2} \mathrm{PO}_{4}$. Previous experience had shown that within-replicate variability is higher than for automated elemental analysis and so all samples were analysed in triplicate. In the present study, the median within-replicate CV was $8.9 \%$.

It is not technically feasible to separate inorganic $\mathrm{C}$ or $\mathrm{P}$ from the organic components in oven-dried tissue prior to analysis. Inorganic $\mathrm{C}$ can be estimated from the $\mathrm{C}$ retained in ash after ignition at relatively low temperatures $\left(500\right.$ to $\left.550^{\circ} \mathrm{C}\right)$; higher ignition temperatures result in the decomposition of skeletal carbonate. Mineral ash contains a variety of oxides of $\mathrm{P}$ from both inorganic and organic $P$, but conversion is not always quantitative (for example in the present study only $~ 80 \%$ of tissue $\mathrm{P}$ was retained in ash of Parborlasia corrugatus, whereas in Heterocucumis steineni retention was complete). The techniques used in this study, therefore, provide measures of organic $\mathrm{C}$, inorganic $\mathrm{C}$, total $\mathrm{N}$ and total $\mathrm{P}$.

Statistical analysis. All statistical analysis was undertaken using Minitab v14 (Pennsylvania State University and Minitab). In all cases the threshold for statistical significance was taken as $\mathrm{p}=0.05$. Differences between sites and seasons were tested using both ANOVA (site or season as fixed factor) and a General Linear Model. Scaling relationships were examined with a model 1 least-squares regression of absolute mass of element per individual on ash-free dry mass, with both variables log-transformed (natural $\operatorname{logs}$ ); non-isometric scaling was indicated by a slope significantly different from unity.

\section{RESULTS}

Although an organism must obtain all of its components, both organic and skeletal, from the environment, correction of whole body composition data for the inorganic fraction allows a direct comparison across taxa of the composition of tissue organic matter. In undertaking comparative studies of tissue stoichiometry it is, therefore, important to correct the elemental composition observed in dry tissue for any $\mathrm{C}$ or $\mathrm{P}$ that forms part of the skeleton or mineral ash component of tissue. If this is not done (for example by analysing molluscs with their shells), then comparison with non-shelled taxa is confounded. The principal errors come from $\mathrm{C}$ retained in skeletal carbonate or $\mathrm{P}$ in those organisms whose skeleton contains significant quantities of phosphate. Skeletal carbonate can readily be estimated from the C retained in mineral ash after ignition at $550^{\circ} \mathrm{C}_{i}$ at this temperature the bulk of organic carbon is oxidised, but most inorganic carbonate is retained. This technique does not work for P (see 'Materials and methods') and here the only approach is to analyse total $\mathrm{P}$.

Some inorganic carbonate was observed in all the taxa studied (Table 2), but, with the exception of the cushion star Odontaster validus, levels were very low. The carbon in dry matter value was corrected for inorganic carbon in all taxa, though only in O. validus was this correction significant. In all other taxa effectively all of the $\mathrm{C}$ and $\mathrm{N}$ was located in the organic matter.

\section{Water and mineral ash content}

In most marine invertebrates ash comprises $\sim 10$ to $15 \%$ of dry tissue (Nicol 1967), and all of the species studied fell within this range with the exception of the 
Table 2. Dry mass and ash content in 6 Antarctic benthic marine invertebrates. (See Table 1 for full species names.) Where animals were sampled at Rothera both in winter (W) and summer (S), data are presented separately; nd $=$ no data. $\mathrm{SE}=$ standard error; data that were not normally distributed (Anderson-Darling test, threshold $\mathrm{p}=0.05$ ) are identified by an asterisk ( ${ }^{*}$ )

\begin{tabular}{|c|c|c|c|c|c|c|c|}
\hline \multirow[t]{2}{*}{$\begin{array}{l}\text { Species } \\
\text { Location }\end{array}$} & \multirow[t]{2}{*}{$\mathrm{n}$} & \multicolumn{2}{|c|}{$\begin{array}{c}\text { Dry mass } \\
\text { (\% wet mass) }\end{array}$} & \multicolumn{2}{|c|}{$\begin{array}{c}\text { Ash } \\
(\% \text { dry mass })\end{array}$} & \multicolumn{2}{|c|}{$\begin{array}{c}\text { C } \\
(\% \text { ash })\end{array}$} \\
\hline & & Mean & $\mathrm{SE}$ & Mean & $\mathrm{SE}$ & Mean & $\mathrm{SE}$ \\
\hline \multicolumn{8}{|l|}{ Parborlasia } \\
\hline Signy & 82 & 18.54 & 1.66 & 13.99 & $2.81^{*}$ & nd & \\
\hline Rothera S & 29 & 13.06 & 1.27 & 17.74 & $2.72^{*}$ & 0.12 & 0.05 \\
\hline \multicolumn{8}{|l|}{ Nacella } \\
\hline Signy & 30 & 20.9 & 0.42 & 18.4 & $1.63^{*}$ & nd & \\
\hline Rothera W & 50 & 18.4 & 0.28 & 17.5 & $0.97^{*}$ & 0.44 & 0.06 \\
\hline Rothera S & 39 & nd & & 25.0 & $0.59^{*}$ & 0.25 & 0.05 \\
\hline \multicolumn{8}{|l|}{ Flabelligera } \\
\hline Rothera S & 30 & 8.21 & 0.26 & 53.4 & $1.51^{*}$ & 0.01 & 0.03 \\
\hline \multicolumn{8}{|l|}{ Thelepus } \\
\hline Rothera W & 30 & 18.9 & 0.57 & 15.7 & 0.70 & 0.16 & 0.03 \\
\hline Rothera S & 27 & 21.9 & 0.55 & 13.0 & 0.73 & 0.16 & 0.04 \\
\hline \multicolumn{8}{|l|}{ Odontaster } \\
\hline Signy & 15 & 15.9 & 0.59 & 56.7 & 1.37 & nd & \\
\hline Rothera S & 39 & 20.1 & 0.46 & 45.1 & 0.87 & 7.65 & 0.13 \\
\hline \multicolumn{8}{|c|}{ Heterocucumis } \\
\hline Rothera W & 12 & 14.0 & 0.64 & 22.8 & 1.44 & 1.61 & 0.41 \\
\hline Rothera S & 6 & 10.9 & 0.51 & 27.4 & 1.32 & 0.17 & 0.04 \\
\hline
\end{tabular}

\& Weiner 1983, Simkiss \& Wilbur 1989). Whilst amorphous hydrous ferric phosphate has been characterised from the tropical Molpadia intermedia (Lowenstam \& Rossman 1975), it would appear that the presence of opal remains anecdotal. The data reported here suggest that the body wall of Heterocucumis does contain spicules, but that these are not carbonate.

Whereas in most marine invertebrates variation in water content and ash content are decoupled, in Parborlasia corrugatus and Heterocucumis steineni they were tightly correlated. In both species a large proportion of the variation could be explained by a simple model that assumes the extra water and ash in larger individuals were caused by a higher content of seawater of salinity 35 (Fig. 2). Nemerteans have a highly variable shape, ranging from fully rounded to flat and ribbon-like (leading to the colloquial name for the phylum of ribbon worms), and they undoubtedly ingest some seawater when engulfing prey. The reason for the variable seawater content of $H$. steineni is unclear.

\section{Elemental composition} steineni, and the limpet Nacella concinna at Rothera in summer (Table 2). The ash content of $O$. validus is very high and differed significantly between Signy and Rothera (Table 2). This high inorganic carbon content is typical of asteroids, which have an internal skeletal structure comprising dispersed ossicles of calcite (Nichols 1967, Lawrence 1987). Simple calculation, assuming that skeletal carbonate is added to a background mineral ash content of $15 \%$ dry mass, suggests that increasing total mineral ash content to the observed value of $45 \%$ dry mass should result in an ash carbon content of $\sim 8 \%$. The value observed for $O$. validus was $7.7 \%$ (Table 2), indicating that the increased ash content in this species was caused almost entirely by the elaboration of a carbonate skeleton.

The holothurian body wall is less skeletonised than those in other echinoderm classes, but many species do contain dispersed spicules (Lawrence 1987), and this probably explains the higher ash content of Heterocucumis steineni. These spicules are often calcareous (Hampton 1958, Stricker 1986), but in H. steineni the carbon content of the mineral ash was too low, equivalent to a carbonate content of $\sim 0.4 \%$ of the ash, for carbonate to explain the higher ash content. The mineralogy of holothurian spicules is complex (Lawrence 1987) with a wide variety of biogenic minerals having been reported, including opal (silica) (Lowenstam
The elemental composition showed species-specific features. The data analysis concentrates on those features that have attracted particular attention in studies of freshwater zooplankton and benthos, namely the absolute concentration of phosphorus in tissue, covariation between carbon, nitrogen and phosphorus, and relationship between molar ratios of carbon, nitrogen and phosphorus (Sterner \& Elser 2002).

The 6 species analysed in this study showed a range or organic tissue elemental concentrations, though all fell within the normal range for marine invertebrates: C concentrations were 49 to $60 \%, \mathrm{~N}$ concentrations 10 to $14 \%$ and $\mathrm{P}$ concentrations 0.7 to $1.3 \%$ (all on an organic matter basis) (Table 3). Within-species variability in elemental composition varied across taxa, and was high in Flabelligera mundata and Odontaster validus and lowest in Parborlasia cornigatus and Thelepus cincinnatus. In all cases, however, variability in $\mathrm{P}$ exceeded that of $\mathrm{C}$ and $\mathrm{N}$, typically by a factor of 2 to 3 .

There were marked variations across taxa in the concentration of all 3 elements in organic matter. The concentration of $\mathrm{C}$ was highest in Heterocucumis steineni, intermediate in the 2 polychaetes and lowest in Parborlasia cornigatus, whereas the concentra- 

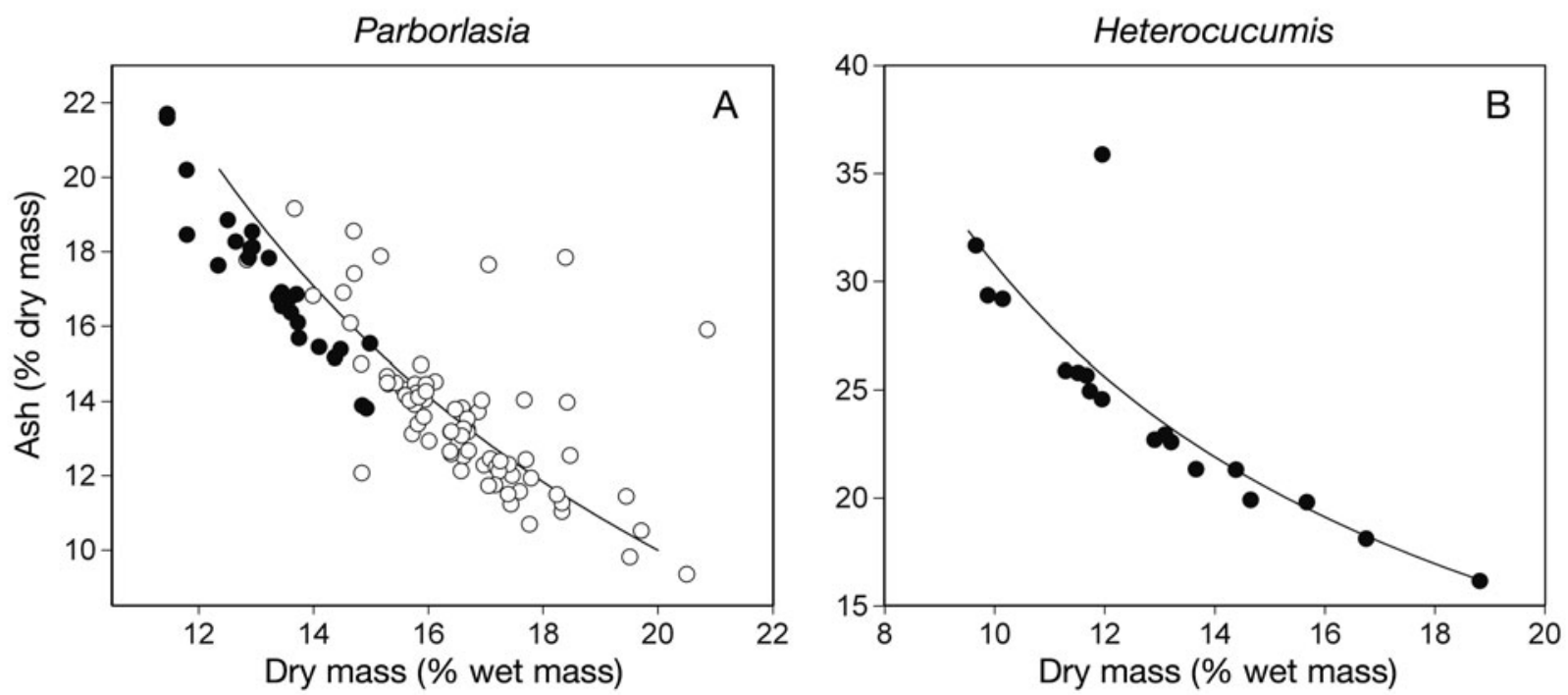

Fig. 2. Covariation of water content and mineral ash content in 2 benthic marine invertebrates. In both cases water content is expressed as its reciprocal (dry mass as \% wet mass). (A) The nemertean Parborlasia corrugatus. Data are for worms sampled from Signy (open symbols) and Rothera (solid symbols), and the line is a model assuming that a worm with $80 \%$ water content contains $10 \%$ dry mass as ash, and that covariation of water and ash content is explained solely by an intake of seawater of salinity 35 . (B) The holothurian Heterocucumis steineni sampled from Rothera. The line is a model assuming that an individual with $81 \%$ water content contains $17 \%$ dry mass as ash, and that covariation of water and ash content is explained solely by an intake of seawater of salinity 35

tion of $\mathrm{N}$ showed essentially the reverse trend. Together these 2 trends result in a marked systematic variation in the $\mathrm{C}: \mathrm{N}$ ratio across the 6 species, with the lowest value in the predator $P$. corrugatus and the highest values in the suspension feeders $H$.

Table 3. Concentration of carbon, nitrogen and phosphorus in organic matter of 6 Antarctic benthic marine invertebrates. (See Table 1 for full species names.) Data expressed as percentage of ash-free dry mass, and corrected for inorganic carbon. Where animals were sampled at Rothera both in winter (W) and summer (S), data are presented separately

\begin{tabular}{|c|c|c|c|c|c|c|c|}
\hline \multirow[t]{2}{*}{$\begin{array}{l}\text { Species } \\
\text { Location }\end{array}$} & \multirow[t]{2}{*}{$\mathrm{n}$} & \multicolumn{2}{|c|}{$\frac{\mathrm{C}}{\text { (\% organic mass) }}$} & \multicolumn{2}{|c|}{$\frac{\mathrm{N}}{\text { (\% organic mass) }}$} & \multicolumn{2}{|c|}{$\begin{array}{c}\mathrm{P} \\
(\% \text { organic mass }\end{array}$} \\
\hline & & Mean & SE & Mean & $\mathrm{SE}$ & Mean & SE \\
\hline \multicolumn{8}{|l|}{ Parborlasia } \\
\hline Signy & 80 & 48.7 & 0.16 & 13.6 & 0.06 & 1.21 & 0.02 \\
\hline Rothera S & 29 & 48.8 & 0.50 & 13.5 & 0.09 & 1.12 & 1.19 \\
\hline \multicolumn{8}{|l|}{ Nacella } \\
\hline Signy & 25 & 48.8 & 0.97 & 10.6 & 0.30 & 1.03 & 0.15 \\
\hline Rothera W & 80 & 49.5 & 1.00 & 12.6 & 0.24 & 1.34 & 0.25 \\
\hline Rothera S & 39 & 49.4 & 4.86 & 12.6 & 0.18 & 1.07 & 0.15 \\
\hline \multicolumn{8}{|l|}{ Flabelligera } \\
\hline Rothera S & 29 & 51.1 & 2.71 & 11.3 & 0.61 & 0.95 & 0.06 \\
\hline \multicolumn{8}{|l|}{ Thelepus } \\
\hline Rothera W & 30 & 52.1 & 0.70 & 10.9 & 0.15 & 1.03 & 0.03 \\
\hline Rothera S & 27 & 53.1 & 0.75 & 11.2 & 0.20 & 1.01 & 0.05 \\
\hline \multicolumn{8}{|l|}{ Odontaster } \\
\hline Signy & 16 & 49.5 & 1.08 & 12.6 & 0.40 & 0.77 & 0.06 \\
\hline Rothera S & 39 & 50.7 & 0.91 & 11.5 & 0.22 & 0.74 & 0.05 \\
\hline \multicolumn{8}{|c|}{ Heterocucumis } \\
\hline Rothera W & 12 & 55.5 & 1.01 & 9.8 & 0.26 & 0.81 & 0.05 \\
\hline Rothera S & 6 & 59.5 & 2.93 & 10.4 & 0.75 & 0.68 & 0.02 \\
\hline
\end{tabular}

steineni and Thelepus cincinnatus (Fig. 3A). The concentration of $\mathrm{P}$ was highest in $P$. corrugatus and Nacella concinna, intermediate in the 2 polychaetes and lowest in the 2 echinoderms (Fig. 3B). The variation in all 3 components across taxa was highly significant (1-way ANOVA with species as fixed factor, all $\mathrm{p}<0.001$ ).

There was no consistent pattern across taxa of within-species scaling in elemental concentration with body mass. To allow for bias introduced by systematic variation in ash content with size, these relationships were examined for concentration in organic matter (ash-free dry mass). To avoid statistical problems when concentration is plotted as a function of biomass (where the mass term appears in both variables), data were plotted as absolute mass of element, with both variables $\log _{\mathrm{e}}$-transformed (see 'Materials and methods'). Phosphorus concentration scaled positively with body mass in 3 species (Parborlasia corrugatus, Nacella concinna, Flabelligera mundata) and negatively in one (Odontaster validus), and only in $N$. concinna did carbon, nitrogen and phosphorus all scale positively. In Heterocucumis steineni carbon and nitrogen scaled negatively, but phos- 

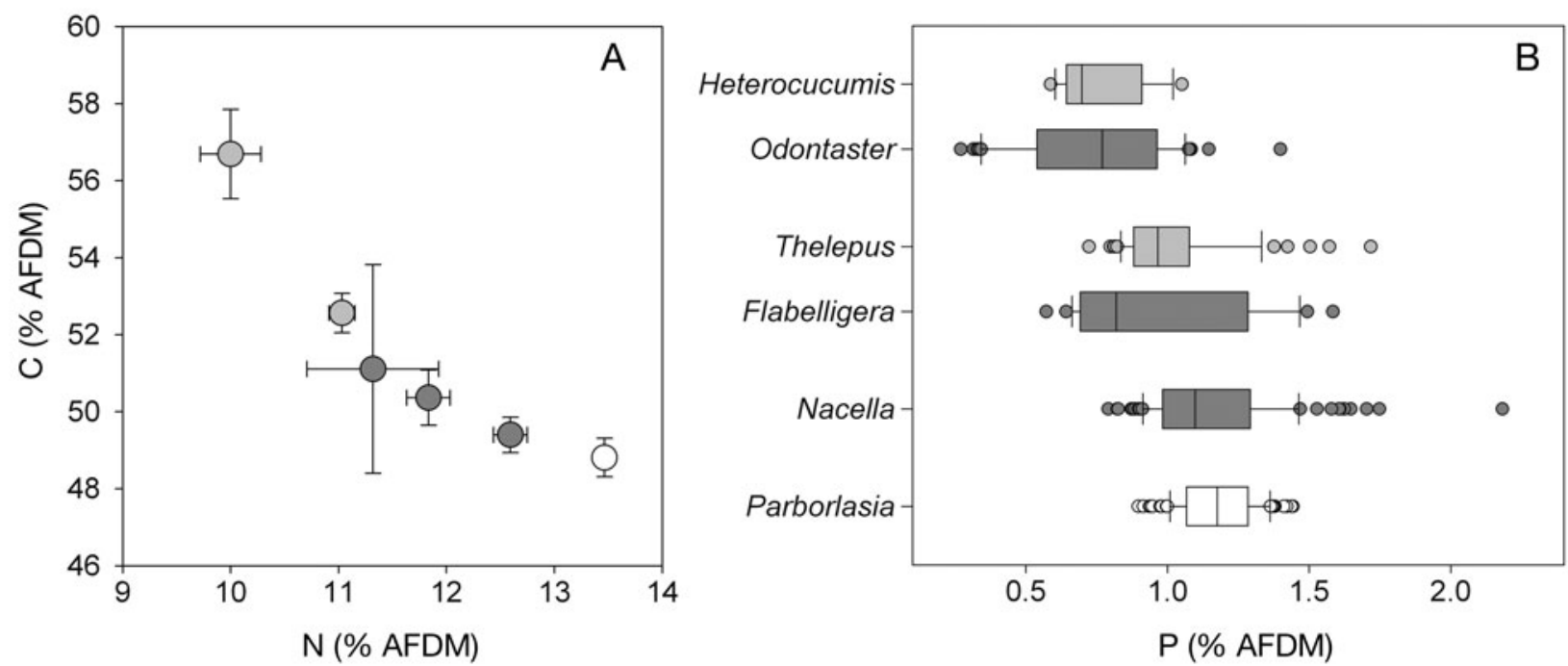

Fig. 3. (A) Relationship between carbon and nitrogen concentration in organic matter (ash-free dry mass, AFDM) for all 6 species examined in this study. (See Table 1 for full species names.) Data are mean values for each species, with error bars showing \pm 1 SE, and boxes are colour coded for feeding type (the predator in white, suspension feeders in light grey and omnivores and grazers in dark grey). (B) Box plot summary of phosphorus concentration in organic matter (AFDM). The box covers the interquartile range with the median marked, the line covers the upper and lower quartiles, and individual outliers are shown as solid circles. Taxa from the same phyla are grouped together (echinoderms at the top, polychaetes in the middle, and 1 mollusc and 1 nemertean at the bottom), and boxes are colour coded by feeding type as for (A)

phorus showed no significant relationship. When compared across species, there was no relationship between body mass (mean or median) and tissue phosphorus content (both $\mathrm{p}>0.05$ ) with species as a fixed factor, however, showed that the variation across taxa was highly significant for $\mathrm{C}: \mathrm{N}(F=$ 223, df $=333, \mathrm{p}<0.001), \mathrm{C}: \mathrm{P}(F=44.3, \mathrm{df}=346, \mathrm{p}<0.001)$ and also $\mathrm{N}: \mathrm{P}(F=29.4, \mathrm{df}=333, \mathrm{p}<0.001)$. The latter was, however, driven principally by the data for Odontaster

\section{Stoichiometry}

Whilst data on the individual elements can be instructive, and carbon and nitrogen data together may be used to estimate proximate composition (Gnaiger \& Bitterlich 1984), the most recent theory has been directed at stoichiometric relationships. For ecology the most informative stoichiometries have proved to be $\mathrm{C}: \mathrm{N}, \mathrm{C}: \mathrm{P}$ and N:P molar ratios (Sterner \& Elser 2002).

The stoichiometric ratios observed for marine benthos in the present study are summarised in Table 4 . The strongest variation across taxa was shown by the C:N molar ratio in organic matter, with the lowest value in the nemertean Parborlasia corrugatus and the highest in the holothurian Heterocucumis steineni (Fig. 4A), reflecting the variation in the concentration of $\mathrm{C}$ and $\mathrm{N}$ across taxa. The pattern of variability across taxa was less clear in both the C:P molar ratio (Fig. 4B) and the N:P molar ratio (Fig. 4C). ANOVA
Table 4. Molar elemental ratios in 6 Antarctic benthic marine invertebrates. (See Table 1 for full species names.) All data are expressed on a molar basis, and calculated for the organic matter fraction (that is, carbon values exclude carbon in the inorganic carbonate in mineral ash). Where animals were sampled at Rothera both in winter (W) and summer (S), data are presented separately; seasonal data are combined where these are not statistically significant $(p>0.05)$

\begin{tabular}{|c|c|c|c|c|c|c|c|}
\hline \multirow{2}{*}{$\begin{array}{l}\text { Species } \\
\text { Site }\end{array}$} & \multirow[t]{2}{*}{$\mathrm{n}$} & \multicolumn{2}{|c|}{$\mathrm{C}: \mathrm{N}$} & \multicolumn{2}{|c|}{$\mathrm{C}: \mathrm{P}$} & \multicolumn{2}{|c|}{$\mathrm{N}: \mathrm{P}$} \\
\hline & & Mean & $\mathrm{SE}$ & Mean & $\mathrm{SE}$ & Mean & $\mathrm{SE}$ \\
\hline \multicolumn{8}{|l|}{ Parborlasia } \\
\hline Signy S & 79 & 4.19 & 0.02 & 105.1 & 1.43 & 25.2 & 0.33 \\
\hline Rothera S & 29 & 4.23 & 0.05 & 117.0 & 1.52 & 27.7 & 0.39 \\
\hline \multicolumn{8}{|l|}{ Nacella } \\
\hline Signy S & 25 & 5.37 & 0.13 & 125.4 & 4.87 & 23.1 & 1.00 \\
\hline Rothera W & 49 & 4.60 & 0.05 & 120.6 & 2.22 & 26.3 & 0.55 \\
\hline Rothera S & 39 & 4.53 & 0.03 & 97.9 & 2.96 & 21.1 & 0.67 \\
\hline \multicolumn{8}{|l|}{ Flabelligera } \\
\hline Rothera S & 25 & 5.31 & 0.11 & 158.2 & 10.9 & 29.5 & 1.77 \\
\hline \multicolumn{8}{|l|}{ Thelepus } \\
\hline Rothera W & 30 & 5.95 & 0.09 & 132.9 & 3.42 & 23.9 & 0.67 \\
\hline Rothera S & 27 & 5.51 & 0.09 & 140.9 & 5.15 & 26.1 & 1.07 \\
\hline \multicolumn{8}{|l|}{ Odontaster } \\
\hline Signy S & 15 & 4.60 & 0.07 & 182.4 & 16.4 & 39.9 & 3.65 \\
\hline Rothera S & 39 & 5.14 & 0.03 & 215.4 & 18.1 & 42.0 & 3.52 \\
\hline \multicolumn{8}{|c|}{ Heterocucumis } \\
\hline Rothera W & 12 & 6.63 & 0.12 & 183.6 & 12.6 & 27.4 & 1.17 \\
\hline Rothera S & 6 & 6.73 & 0.28 & 219.1 & 6.89 & 32.7 & 1.53 \\
\hline
\end{tabular}



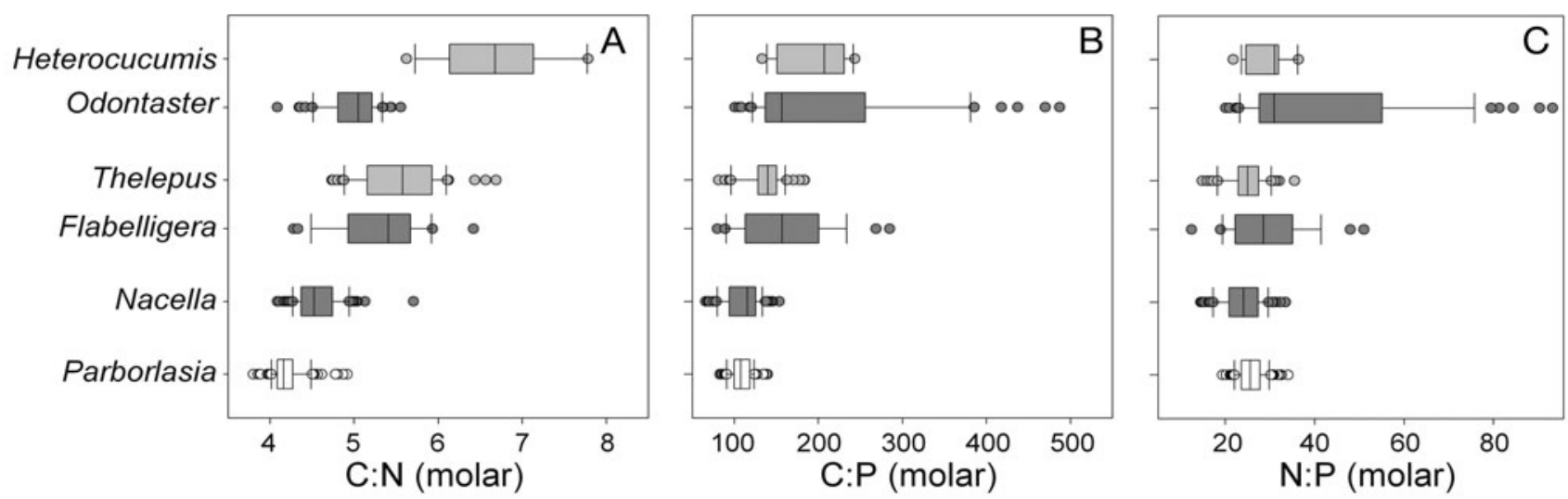

Fig. 4. Box-plot summaries of elemental stoichiometries for 6 species of Antarctic benthic marine invertebrates. (A) C:N, (B) C:P, (C) N:P molar ratios. (See Table 1 for full species names.) Presentation as for Fig. 3B

validus and removing this species from the analysis reduced overall variability in N:P to non-significant levels.

These patterns suggest that a major component in overall stoichiometric variability is species-specific variation in a component of fixed $\mathrm{N}: \mathrm{P}$ ratio. The 2 major tissue components that are rich in both nitrogen and phosphorus are membrane phospholipids and nucleic acids. Of these, phospholipids might be expected to maintain a fairly constant relationship to organic matter $(\sim 5 \%$ body mass, Sterner \& Elser 2002), except in females undergoing gonad maturation. Many marine invertebrate eggs are rich in phospholipids (Clarke et al. 1990, Clarke \& Gore 1992, Clarke 1993), and this extra phospholipid affects the proximate and elemental composition of maturing females (Clarke 1983, Ventura \& Catalan 2005). Lipid was not examined in the present study, but a previous analysis of lipid and lipid $\mathrm{P}$ in marine invertebrates from South Georgia indicated significant variation in the concentration of lipid P across taxa (Clarke 1983). The concentration of lipid $\mathrm{P}$ in organic matter varied from $\sim 30 \mu \mathrm{mol} \mathrm{g}^{-1}$ in the ophiuroid Ophionotus hexactis to $\sim 70 \mu \mathrm{mol} \mathrm{g}^{-1}$ in the gastropod Chlanidota densesculpta, and $O$. validus. These values equate to concentrations of phospholipid in tissue of 2 to $6 \%$, which is typical for invertebrate tissue (Sterner \& Elser 2002). Most of this variation was associated with differences in overall lipid content, indicating that although neutral lipid (triacylglcycerol) is the major storage lipid in polar benthic marine invertebrates, phospholipid is also an important component in maturing females (Clarke 1983).

\section{DISCUSSION}

In this study 6 marine invertebrates of differing trophic niches have been analysed. Although the results from each individual taxon are interesting in terms of what they can tell us about that individual species' own ecology, it is the general trends that contribute most to our understanding of ecological processes. Therefore, we need to set the data reported in this investigation in the context of previous studies of marine invertebrate composition, and the stoichiometric relationships established for zooplankton, nekton and freshwater benthic invertebrates.

\section{Water and ash content}

In 5 of the 6 species examined, mean water contents were in the range of 80 to $85 \%$ wet mass, which is typical for marine invertebrates (Nicol 1967). The exception was the deposit-feeding polychaete Flabelligera mundata, where mean water content exceeded $90 \%$ (Table 2). In 3 species the mineral ash content of the dry mass was in the range of 13 to $18 \%$, which is typical for marine invertebrates without a substantial inorganic skeleton (Nicol 1967; note that data for the limpet Nacella concinna exclude the external shell). The holothurian Heterocucumis steineni had a slightly higher ash content, probably as a result of spicules in the body wall. Two species had high ash contents; in $F$. mundata this was presumably related to sediment in the gut, whereas in Odontaster validus this reflected the calcite spicules in the body wall. $O$. validus was the only species examined where a correction was needed for inorganic carbon to allow accurate estimate of organic stoichiometry.

In 2 species, the predatory nemertean Parborlasia corrugatus and the holothurian Heterocucumis steineni, water and ash covaried in a manner suggesting a variable content of seawater (Fig. 1). In P. corrugatus these variations may have been associated with feeding, but the cause of the variation in $H$. steineni is unclear. 


\section{Comparison with freshwater benthos}

Two recent studies of elemental composition and stoichiometry in freshwater benthos have demonstrated marked variations between different taxa, between sites and between seasons. Benthic invertebrates (insects, molluscs and crustaceans) from streams in 2 areas of North America showed little variation in composition with size, but marked variation between taxa and, in the case of insects, also between species. Phosphorus was the most variable component and the N:P molar ratio differed between feeding guilds, increasing in the sequence, scrapers-filterers-predators (Evans-White et al. 2005). In benthic invertebrates from Lake Erken in Sweden the majority of the variability in elemental composition of stoichiometry was explained by taxonomic group, though there were also differences between sites and seasons for some taxa (Liess \& Hillebrand 2005).

Marine organisms typically live in a different nutrient environment from those in freshwater in that typically neither $\mathrm{N}$ nor $\mathrm{P}$ is limiting (except in surface waters at the end of the summer phytoplankton bloom in some areas). Nevertheless, the marine benthos examined in this study showed elemental compositions broadly similar to those of freshwater benthos, with the exception of a higher $\mathrm{P}$ content. There was marked variability across taxa and also between sites for those species sampled from both Signy Island and Rothera (Tables 2, $3 \& 4$ ). The differences in composition across taxa were all highly significant (1-way ANOVA with species as fixed factor, all $\mathrm{p}<0.001)$. A nested ANOVA with species grouped by phylum indicated that the most of the variation was explained by phylum rather than by species within phylum (for $\mathrm{P}$ concentration, $42 \%$ versus $<1 \%$, respectively). The limited range of species and the unbalanced analysis does, however, constrain the strength of this conclusion.

There is limited overlap between the groups of organisms examined in this marine study and previous analyses of freshwater benthos, with insects being confined to freshwater habitats and nemerteans and echinoderms to marine ones. Comparison is, however, possible for molluscs for those studies where the tissue

Table 5. Comparison of the elemental composition (\% dry mass) of freshwater and marine molluscs. Stream data from Evans-White et al. (2005), Lake Erken data from Liess \& Hillebrand (2005). Data presented as mean with SE in parentheses

\begin{tabular}{|c|c|c|c|c|}
\hline Site & $\begin{array}{c}\text { No. of } \\
\text { species }\end{array}$ & $\mathrm{C}$ & $\mathrm{N}$ & $\mathrm{P}$ \\
\hline North American streams & 11 & $42.2(3.6)$ & $9.6(1.6)$ & $0.81(0.13)$ \\
\hline Lake Erken, Sweden & 4 & $42.0(1.3)$ & $10.3(0.31)$ & $0.59(0.019)$ \\
\hline Marine Antarctic & 1 & $39.4(4.1)$ & $9.7(1.2)$ & $0.91(0.14)$ \\
\hline
\end{tabular}

was removed from the shell. Calculated on a dry mass basis, the freshwater molluscs generally had slightly higher $\mathrm{C}$ contents, similar $\mathrm{N}$ contents and slightly lower P contents than did the marine mollusc N. concinna (Table 5). Overall, however, there was no indication that the lower nutrient contents that typify freshwater habitats were reflected in the tissue composition of benthic invertebrates when compared with those from the more nutrient replete marine environment.

\section{Growth rate hypothesis}

Nucleic acid content, and particularly RNA content, varies with growth rate. Rapidly growing organisms need to increase the number of ribosomes in the cell, and this is reflected in tissue stoichiometry and, particularly, in a higher phosphorus content. This relationship has been formulated as the growth rate hypothesis (Elser et al. 1996, Main et al. 1997, Sterner \& Elser 2002) and has been explored within the framework of both dynamic energy budget theory (Vrede et al. 2004) and the metabolic theory of ecology (Gillooly et al. 2005). Empirical data have largely confirmed the prediction of a positive correlation between growth rate and phosphorus content (Elser et al. 1996, Sterner \& Elser 2002) in freshwater and terrestrial systems. In Antarctic krill Euphausia superba there was no correlation in the short term, but seasonally averaged data did match the predictions of the growth rate hypothesis (Arnold et al. 2004).

We cannot test the growth rate hypothesis directly with the data from this study because we have growth data for only one of the species (Nacella concinna, Clarke et al. 2004). However, since polar marine invertebrates generally have slow growth rates (Clarke 1983, Brey \& Clarke 1993), we might expect their phosphorus contents to be towards the lower end of the range observed overall, but this is not what we observed. Mean P contents ranged from $0.75 \%$ organic matter in Odontaster validus to $1.16 \%$ in N. concinna (Fig. 3a), and these are above the values typical of freshwater invertebrates (Sterner \& Elser 2002, Evans-White et al. 2005, Liess \& Hillebrand 2005). There are 2 possible explanations for this. The first is that the relationship in marine invertebrates is offset from that of freshwater invertebrates such that for any given growth rate $\mathrm{P}$ content is higher in marine taxa from that in freshwater taxa (where P is frequently limiting). The second is that the growth rate-phosphorus relationship breaks down at low temperatures as a result of the higher mRNA and ribosomal RNA contents to offset temperature constraints on the rates of transcription and 


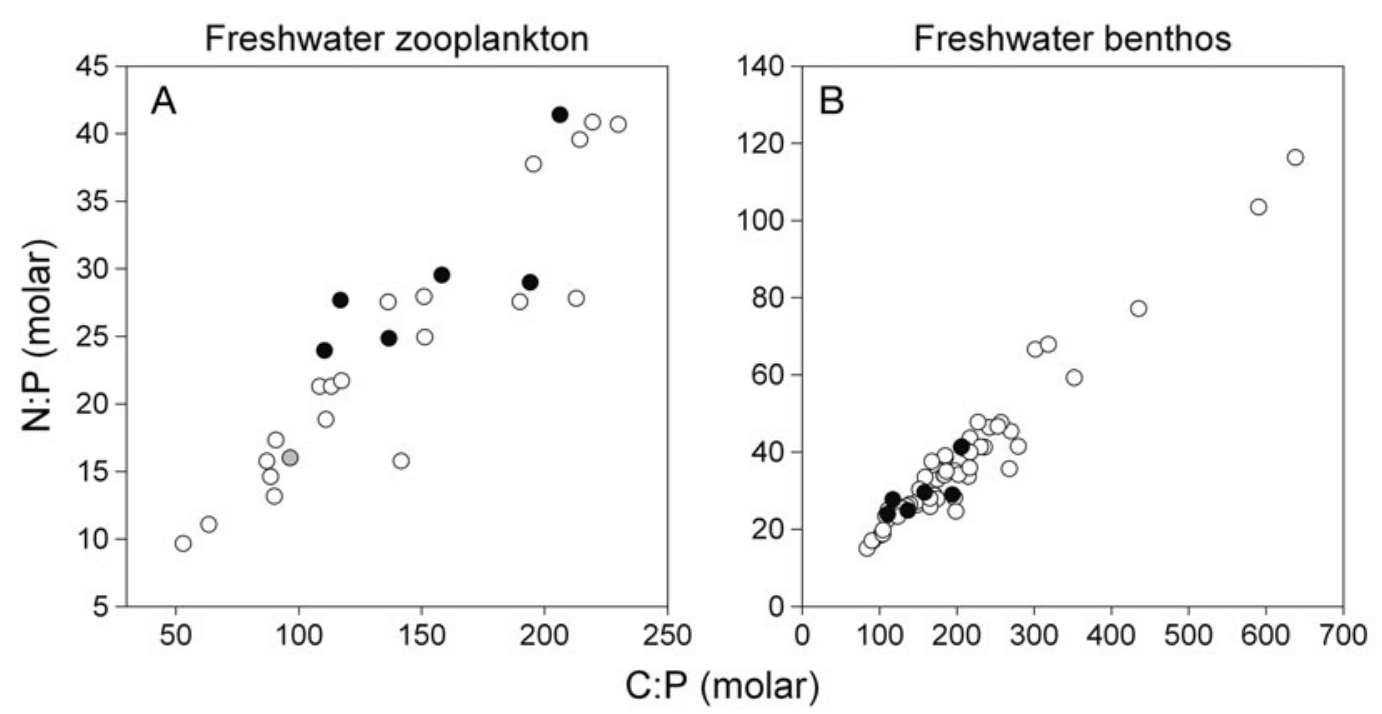

Fig. 5. Relationship between N:P and C:P molar ratios for 6 benthic marine invertebrates (solid black symbols) in relation to patterns established for other taxa. (A) Comparison with a range of freshwater zooplankton (open symbols) and Antarctic krill, Euphausia superba (solid grey symbols). Freshwater data are from Sterner \& Elser (2002) and Antarctic krill data from Arnold et al. (2004). (B) Comparison with freshwater benthos (open symbols); data from Evans-White et al. (2005) and Liess \& Hillebrand (2005)

translation in polar species (Fraser et al. 2007). This also results in the C:P ratio not being markedly high, and it may be that a simple relationship between growth rate and RNA content, as expressed in the growth rate hypothesis, may not be upheld in polar taxa, where low growth rates are associated with relatively high RNA contents.

\section{Stoichiometry}

Whilst the overall pattern in stoichiometric ratios across the range of species examined in this study points to important variation in nucleic acid content, there was also a marked covariation in carbon and nitrogen concentration in organic matter (Fig. 5A). Whilst care must always be exercised in interpreting normalised data (if one component increases at least one other must decrease since the sum of all components is fixed), the data do point to a shift in protein content from $\sim 60 \%$ organic matter in Heterocucumis steineni to $\sim 80 \%$ in Parborlasia corrugatus. Simple modelling (Gnaiger \& Bitterlich 1984) indicates that variations in tissue composition limited to simply a switch in the ratio of protein to lipid would lead to a linear relationship between the concentrations of carbon and nitrogen concentration in organic matter; the observed non-linear pattern (Fig. 4B) indicates that the different species analysed in this study exhibit a more complex variation in the major components of organic matter. Thus, the results indicate that there are no stoichiometric features common to all taxa examined; instead there are species-specific patterns reflecting differences in the proximate (protein, carbohydrate, lipid, nucleic acid) composition of organic matter.

\section{Influence of trophic level}

Much experimental work on ecological stoichiometry has been concerned with either autotrophs or heterotrophs feeding at the first consumer level (that is, herbivores). Relatively few studies have examined higher tropic levels such as carnivores, or detritivores, but recent work on benthic invertebrates from freshwater habitats has pointed to variations in elemental composition and stoichiometric ratios in relation to feeding guild (Evans-White et al. 2005, Liess \& Hillebrand 2005). The summary by Sterner \& Elser (2002) suggests a narrowing of the range of C:P stoichiometries from primary producers through herbivores to higher level consumers, caused by dissipation of carbon at each step in the food web. Evans-White et al. (2005) demonstrated a lowering of C:P values, and a narrowing of the range of values, in comparing the composition of food with that of different feeding guilds in stream invertebrates. They also showed an increase in the N:P ratio towards higher trophic levels.

Of the 6 benthic marine invertebrates examined in this study, 2 could be regarded as feeding directly on primary production (the suspension feeders Heterocucumis steineni and Thelepus cincinnatus). The others are a carnivore (Parborlasia corrugatus), an omnivore (Odontaster validus), a grazer of benthic microbial 
films (Nacella concinna) and a deposit feeder (Flabelligera mundata). This variety of feeding types makes statistical analysis problematical, but there was a clear tendency for the predator to have the lowest $\mathrm{C}: \mathrm{N}$ ratio, and suspension feeders the highest (Fig. 3A). There was no systematic pattern in relation to feeding type in the stoichiometric ratios $\mathrm{C}: \mathrm{P}$ or N:P (Fig. 4). The only clear feature was that the predator $P$. corrugatus had the highest $\mathrm{P}$ content and the lowest $\mathrm{C}: \mathrm{N}$ and $\mathrm{C}: \mathrm{P}$ ratios. Whilst the stoichiometry of the predator and 2 suspension feeders observed in this study match the patterns established for freshwater benthic predators and filter feeders (Evans-White et al. 2005), the small differences in stoichiometric ratios associated with feeding type overall indicate that variations in elemental stoichiometry with trophic level are confounded by species-specific differences in proximate composition.

\section{Broad scale patterns in elemental stoichiometry}

The elemental stoichiometry of Antarctic marine benthos is varied, but falls within the range of values established previously for freshwater benthos. Stoichiometric analyses of a broad range of consumer organisms (zooplankton and fish from both freshwater and marine environments) has demonstrated a strong covariation in N:P and C:P molar ratios (Fig. 5). Whilst covariation plots such as these present statistical difficulties in that the 2 measures share a variable $(\mathrm{P})$, they have become a staple of stoichiometric analysis (Sterner \& Elser 2002). Despite the statistical difficulties, the slope of the plot provides an estimate of the mean $\mathrm{C}: \mathrm{N}$ ratio across taxa, and the variance indicates the range of values observed. Since the tissue of nongelatinous marine invertebrates is dominated by protein, data would be expected to fall within boundaries defined by the C:N ratio of amino acids (1.5 to 9.0). Whilst it would be difficult to conceive of a viable tissue that comprised proteins with such extreme C:N ratios, in taxa such as crustaceans or insects a high chitin ( $\mathrm{C}: \mathrm{N} \sim 8$ ) content or a large skeletal component could push the $\mathrm{C}: \mathrm{N}$ ratio towards the upper boundary. Finally, curvilinearity in the plot would indicate a shift in $\mathrm{C}: \mathrm{N}$ content with variation in $\mathrm{P}$ content.

The data for marine benthos match the pattern established for freshwater zooplankton and Antarctic krill (a marine zooplankton) well (Fig. 5A). The range of $\mathrm{C}: \mathrm{P}$ and $\mathrm{N}: \mathrm{P}$ values is fairly narrow, and the overall slope indicates a mean $\mathrm{C}: \mathrm{N}$ ratio of 5.73 , with the data falling within the range of 4.19 to 8.05 . The range of $\mathrm{C}: \mathrm{P}$ and $\mathrm{N}: \mathrm{P}$ values observed in freshwater benthos is much wider (driven principally by the large variation in the $\mathrm{P}$ content of insects), and the marine data from this study are, thus, confined to the lower left hand side of the graph (Fig. 5B). The slope of the covariation plot remains similar to that for zooplankton; the slope indicates a mean C:N content across taxa of 6.06, with the data falling within the bounds of 4.19 to 9.00 . Some of his variability will be caused by inorganic carbon from those taxa where the analysis includes skeletal carbonate (notably some freshwater molluscs), and in the case of insects by contributions from chitin. The data overall indicate a fairly narrow range of $\mathrm{C}: \mathrm{N}$ ratios in aquatic invertebrate tissue, with the dominant signal coming from the protein that forms the bulk of this tissue. These data tend to confirm the suggestion of Gnaiger \& Bitterlich (1984) that the mass fraction of $\mathrm{N}$ in protein from aquatic invertebrates is around 5.78 rather than the conventional value of 6.25 (which was based predominantly on studies of mammalian tissue).

\section{CONCLUSIONS}

The 3 main conclusions from this work were (1) The elemental composition of the 6 taxa of Antarctic marine benthos was broadly similar to that of freshwater benthos, though with slightly higher P content. (2) The high $\mathrm{P}$ content suggests that the growth rate hypothesis linking growth rate to $\mathrm{P}$ content needs to be modified for species living at low temperatures, where a high RNA content, and hence P content, is coupled with a low growth rate. (3) All stoichiometric ratios (C:N, C:P, N:P) vary across taxa. Overall elemental composition and stoichiometry showed strong differences associated with phylogeny. Whilst these tended to obscure any variation associated with feeding type, the high $\mathrm{P}$ content and low $\mathrm{C}: \mathrm{N}$ ratio of the predatory Parborlasia corrugatus and the high C:N ratios of the suspension feeders Heterocucumis steineni and Thelepus cincinnatus matched patterns established for freshwater benthos.

Acknowledgements. The collection of samples and subsequent elemental analysis has taken place over a number of years. It is a pleasure to acknowledge E. Prothero-Thomas, J. C. Beaumont and K. P. P. Fraser for the collection of samples, and E. Prothero-Thomas, L. Cunningham, K. E. Webb and M. P. Barrett for help with the chemical analysis. Four referees provided valuable comments that improved the paper significantly.

\section{LITERATURE CITED}

Anderson TR, Boersma M, Raubenheimer D (2004) Stoichiometry: linking elements to biochemicals. Ecology 85: 1193-1202

Anderson TR, Hessen DO, Elser JJ, Urabe J (2005) Metabolic stoichiometry and the fate of excess carbon and nutrients in consumers. Am Nat 165:1-15 
Arnold KH, Shreeve RS, Atkinson A, Clarke A (2004) Growth rates of Antarctic krill, Euphausia superba: comparison of the instantaneous growth rate method with nitrogen and phosphorus stoichiometry. Limnol Oceanogr 49: 2152-2161

Brey T, Clarke A (1993) Population dynamics of benthic marine invertebrates in Antarctic and Subantarctic environments: Are there unique adaptations? Antarct Sci 5: 253-266

Clarke A (1983) Life in cold water: the physiological ecology of polar marine ectotherms. Oceanogr Mar Biol Annu Rev 21:341-453

Clarke A (1990) Faecal egestion and ammonia excretion in the Antarctic limpet Nacella concinna (Strebel, 1908). J Exp Mar Biol Ecol 138:227-246

$>$ Clarke A (1993) Egg size and egg composition in polar shrimps (Caridea; Decapoda). J Exp Mar Biol Ecol 168: 189-203

Clarke A, Gore DJ (1992) Egg size and composition in Ceratoserolis (Crustacea: Isopoda) from the Weddell Sea. Polar Biol 12:129-134

Clarke A, Leakey RJG (1996) The seasonal cycle of phytoplankton, macronutrients, and the microbial community in a nearshore Antarctic marine ecosystem. Limnol Oceanogr 41:1281-1294

Clarke A, Prothero-Thomas E (1997) The influence of feeding on oxygen consumption and nitrogen excretion in the Antarctic nemertean Parborlasia corrugatus. Physiol Zool 70:639-649

> Clarke A, Brown JH, Holmes LJ (1990) The biochemical composition of eggs from Macrobrachium rosenbergii in relation to embryonic development. Comp Biochem Physiol B Biochem Mol Biol 96:505-511

Clarke A, Prothero-Thomas E, Whitehouse MJ (1994) Nitrogen excretion in the Antarctic limpet Nacella concinna (Strebel, 1908). J Molluscan Stud 60:141-147

Clarke A, Prothero-Thomas E, Beaumont JC, Chapman AL, Brey T (2004) Growth in the limpet Nacella concinna from contrasting sites in Antarctica. Polar Biol 28:62-71

Clarke A, Meredith MP, Wallace MI, Brandon MA, Thomas DN (2008) Seasonal and interannual variability in temperature, chlorophyll and macronutrients in northern Marguerite Bay, Antarctica. Deep-Sea Res II (in press)

Davison W, Franklin CE (2002) The Antarctic nemertean Parborlasia corrugatus: an example of an extreme oxyconformer. Polar Biol 25:238-240

Elser JJ, Urabe J (1999) The stoichiometry of consumer-driven nutrient recycling: theory, observations, and consequences. Ecology 80:735-751

Elser JJ, Dobberfuhl DR, MacKay NA, Schampel JH (1996) Organism size, life history, and N:P stoichiometry: towards a unified view of cellular and ecosystem processing. Bioscience 46:674-684

Elser JJ, Bracken MES, Cleland EE, Gruner DS and others (2007) Global analysis of nitrogen and phosphorus limitation of primary producers in freshwater, marine and terrestrial ecosystems. Ecol Lett 10:1135-1142

Evans-White MA, Stelzer RS, Lamberti GA (2005) Taxonomic and regional patterns in benthic macroinvertebrate elemental composition in streams. Freshw Biol 50:1786-1799

Fiske CH, Subbarow Y (1925) The colorimetric determination of phosphorus. J Biol Chem 66:375-400

Fraser KPP, Clarke A, Peck LS (2002) Feast and famine in Antarctica: seasonal physiology in the limpet Nacella concinna. Mar Ecol Prog Ser 242:169-177

Fraser KPP, Peck LS, Clarke A (2004) Protein synthesis, RNA concentrations, nitrogen excretion, and metabolism vary seasonally in the Antarctic holothurian Heterocucumis steineni (Ludwig 1898). Physiol Biochem Zool 77:556-569

Fraser KPP, Clarke A, Peck LS (2007) Growth in the slow lane: protein synthesis in the Antarctic limpet Nacella concinna (Strebel, 1908). J Exp Biol 210:2691-2699

Fraústo da Silva JJR, Williams RJP (2001) The biological chemistry of the elements: the inorganic chemistry of life. Oxford University Press, Oxford

Geider RJ, La Roche J (2002) Redfield revisited: variability of $\mathrm{C}: \mathrm{N}: \mathrm{P}$ in marine microalgae and its biochemical basis. Eur J Phycol 37:1-17

Gibson R (1983) Antarctic nemerteans: the anatomy, distribution and biology of Parborlasia corrugatus (McIntosh, 1876) (Heteronemertea, Lineidae). Antarct Res Ser 39: 289-316

Gillooly JF, Allen AP, Brown JH, Elser JJ and others (2005) The metabolic basis of whole-organism RNA and phosphorus content. Proc Natl Acad Sci USA 102: 11923-11927

Gnaiger E, Bitterlich G (1984) Proximate biochemical composition and caloric content calculated from elemental CHN analysis: a stoichiometric concept. Oecologia 62:289-298

Grange LJ, Tyler PA, Peck LS (2007) Multi-year observations on the gametogenic ecology of the Antarctic seastar Odontaster validus. Mar Biol 153:15-23

Guildford SJ, Hecky RE (2000) Total nitrogen, total phosphorus, and nutrient limitation in lakes and oceans: Is there a common relationship? Limnol Oceanogr 45:1213-1223

> Hampton JS (1958) Chemical analysis of holothurian sclerites. Nature 181:1608-1609

Heine JN, McClintock JB, Slattery M, Weston J (1991) Energetic composition, biomass, and chemical defense in the common Antarctic nemertean Parborlasia corrugatus McIntosh. J Exp Mar Biol Ecol 153:15-25

Hillebrand H, Sommer U (1999) The nutrient stoichiometry of benthic microalgal growth: Redfield proportions are optimal. Limnol Oceanogr 44:440-446

Iwanami K, Futatsumachi S, Taniguchi A (1986) Short-term variation of chemical property of water and microplankton community in the coastal area near Syowa station, Antarctica, in midsummer of 1984. 1. Chemical property including chlorophyll a. Mem Natl Inst Polar Res 40:1-14

> Jennings JC, Gordon LI, Nelson DM (1984) Nutrient depletion indicates high productivity in the Weddell Sea. Nature 309:51-54

- Karimi R, Folt CL (2006) Beyond macronutrients: element variability and multielement stochiometry in freshwater invertebrates. Ecol Lett 9:1273-1293

Lawrence JM (1987) A functional biology of echinoderms. Croom Helm, London

Liess A, Hillebrand H (2005) Stoichiometric variation in C:N, $\mathrm{C}: \mathrm{P}$, and $\mathrm{N}: \mathrm{P}$ ratios of littoral benthic invertebrates. $\mathrm{J} \mathrm{N}$ Am Benthol Soc 24:256-269

Lindemann RL (1942) The trophic dynamic aspect of ecology. Ecology 23:399-413

Lotka AJ (1925) Elements of physical biology. Williams \& Wilkins, Baltimore, MD

Lowenstam HA, Rossman GR (1975) Amorphous, hydrous, ferric phosphatic dermal granules in Molpadia (Holothuroidea): physical and chemical characterization and ecologic implications of the bioinorganic fraction. Chem Geol 15:15-51

Lowenstam HA, Weiner S (1983) Mineralization by organisms and the evolution of biomineralization. In: Westbroek $\mathrm{P}$, De Jong EW (eds) Biomineralization and biological metal accumulation. D. Reidel, Dordrecht, p 191-203

Main TM, Dobberfuhl DR, Elser JJ (1997) N:P stoichiometry 
and ontogeny of crustacean zooplankton: a test of the growth rate hypothesis. Limnol Oceanogr 42:648-662

McClintock JB, Pearse JS, Bosch I (1988) Population structure and energetics of the shallow water Antarctic sea star Odonaster validus in contrasting habitats. Mar Biol 99: 235-246

Nichols D (1967) Echinoderms. Hutchinson, London

Nicol JAC (1967) The biology of marine animals. John Wiley \& Sons, New York

Pearse JS (1965) Reproductive periodicities in several contrasting populations of Odontaster validus Koehler, a common Antarctic asteroid. In: Llano GA (ed) Biology of Antarctic seas II. Antarct Res Ser, Vol 5. American Geophysical Union, Washington, DC, p 39-85

Pearse JS (1969) Slow developing demersal embryos and larvae of the Antarctic sea star Odontaster validus. Mar Biol 3:110-116

Pearse JS, McClintock JB, Bosch I (1991) Reproduction of Antarctic benthic marine invertebrates; tempos, modes and timing. Am Zool 31:65-80

Redfield AC, Ketchum BH, Richards FA (1963) The influence of organisms on the composition of seawater. In: Hill MN (ed) Comparative and descriptive oceanography. Wiley, New York, p 26-77

Reiners WA (1986) Complementary models for ecosystems. Am Nat 127:59-73

Simkiss K, Wilbur KM (1989) Biomineralization: cell biology

Editorial responsibility: James McClintock,

Birmingham, Alabama, USA and mineral depositions. Academic Press, San Diego, CA Stanwell-Smith D, Clarke A (1998) Seasonality of reproduction in the cushion star Odontaster validus at Signy Island, Antarctica. Mar Biol 131:479-487

Stanwell-Smith DP, Peck LS (1998) Temperature and embryonic development in relation to spawning and field occurrence of larvae of 3 Antarctic echinoderms. Biol Bull (Woods Hole) 194:44-52

Sterner RW, Elser JJ (2002) Ecological stoichiometry: the biology of elements from molecules to the biosphere. Princeton University Press, Princeton, NJ

Sterner RW, Andersen T, Elser JJ, Hessen DO, Hood JM, McCauley E, Urabe J (2008) Scale-dependent carbon: nitrogen: phosphorus stoichiometry in marine and freshwaters. Limnol Oceanogr 53:1169-1180

Stricker SA (1986) The fine structure and development of calcified skeletal elements in the body wall of holothurian echinoderms. J Morphol 188:273-288

Tyrrell $\mathrm{T}$ (1999) The relative importance of nitrogen and phosphorus on oceanic production. Nature 400:525-531

Ventura M, Catalan J (2005) Reproduction as one of the main causes of temporal variability in the elemental composition of zooplankton. Limnol Oceanogr 50:2043-2056

Vrede T, Dobberfuhl DR, Kooijman SALM, Elser JJ (2004) Fundamental connections among organisms C:N:P stoichiometry, macromolecular composition, and growth. Ecology 85:1217-1229

Submitted: March 11, 2008; Accepted: July 28, 2008

Proofs received from author(s): September 30, 2008 